\title{
Induction of Apoptosis by Methyl Alcohol Extract of Enteromorpha linza (Linnaeus) J Agardh in U937 Human Leukemia Cells
}

\author{
Eun-Ok Choi ${ }^{1}$, Hyang-Suk Kim ${ }^{1,3}$, Min-Ho Han ${ }^{2}$, Cheol Park, Byung-Woo \\ $\mathrm{Kim}^{1,2,5}$, Jin Ah Hwang ${ }^{6}$, Yung Hyun Choi ${ }^{1,2,7 *}$ and Hye-Jin Hwang ${ }^{1,2,3 *}$ \\ ${ }^{1}$ Anti-Aging Research Center, ${ }^{2}$ Blue-Bio Industry RIC, Departments of ${ }^{3}$ Food and Nutrition, ${ }^{4}$ Molecular Biology, and ${ }^{5}$ Life \\ Science and Biotechnology, Dongeui University Busan 614-714, ${ }^{6}$ Department of Food and Nutrition, Myongji University, \\ Gyeonggi-do, 449-728, 'D Department of Biochemistry, Dongeui University College of Oriental Medicine, Busan 614-052, \\ Republic of Korea
}

*For correspondence: Email: choiyh@deu.ac.kr, hhj2001@deu.ac.kr, Tel: +82 51850 7413, +82-890-1594

Received: 23 July 2013

Revised accepted: 4 April 2014

\begin{abstract}
Purpose: To investigate the anti-cancer effect of methyl alcohol extract of Enteromorpha linza (Linnaeus) J. Agardh (MEEL) in U937 human leukemia cells.

Methods: Cytotoxicity was evaluated by 3-(4,5-dimethyl-2-thiazolyl)-2,5-diphenyl-2H-tetrazolium bromide (MTT) assay. Apoptosis was detected using 4',6-diamidino-2-phenylindole (DAPI) staining, agarose gel electrophoresis, and flow cytometry. Protein levels were determined by Western blot analysis. Caspase activity was measured spectrophotometrically at $405 \mathrm{~nm}$.

Results: MEEL inhibited U937 cell proliferation and induced apoptosis through up-regulation of death receptor-related gene expression, caspase-8 activation and truncation of Bid, which was associated with the loss of mitochondrial membrane potential. Subsequently, the levels of anti-apoptotic proteins such as Bcl-2 and BCl-xL, and IAP family proteins decreased but those of pro-apoptotic proteins including Bax and Bad increased in MEEL-treated U937 cells. MEEL treatment also resulted in activation of caspase-9 and -3 as well as concomitant cleavage of poly(ADP-ribose) polymerase and phopholipase $\mathrm{CY}$-1. However, pretreatment of U937 cells with z-VAD-fmk, a pan caspase inhibitor, abrogated chromatin condensation and DNA fragmentation and prevented cell death induced by the MEEL.

Conclusion: The findings suggest that MEEL induced apoptosis in U937 cells through a signaling cascade of death-receptor-mediated extrinsic as well as mitochondria-mediated intrinsic pathways, thus raising the possibility that MEEL may be of value in the development of novel therapeutic approaches for treating leukemia.
\end{abstract}

Keywords: Enteromorpha linza, Apoptosis, Caspase, U937 cells

Tropical Journal of Pharmaceutical Research is indexed by Science Citation Index (SciSearch), Scopus, International Pharmaceutical Abstract, Chemical Abstracts, Embase, Index Copernicus, EBSCO, African Index Medicus, JournalSeek, Journal Citation Reports/Science Edition, Directory of Open Access Journals (DOAJ), African Journal Online, Bioline International, Open-J-Gate and Pharmacy Abstracts

\section{INTRODUCTION}

Apoptosis is an active process of cellular selfdestruction with distinct morphological and biochemical features [1,2]. Elucidating the apoptotic mechanism is important for preventing and curing various incurable diseases including cancers [3,4]. Apoptosis may be triggered by a wide variety of death signals, and two major pathways are involved such as the death receptor-mediated (extrinsic) pathway and the mitochondria-initiated apoptotic (intrinsic) 
pathway. The death receptor-mediated pathway is initiated through activation of caspase- 8 by stimulation of transmembrane death receptors located on the cell membrane. Active caspase-8 activates downstream caspases, including caspase-3, and cleaves Bid, a pro-apoptotic Bcl2 family member. Truncated Bid (tBid) induces mitochondrial cytochrome c release [4-7]. In contrast, the mitochondrial apoptotic pathway is initiated through the release of signal factors including cytochrome $\mathrm{c}$ by mitochondria within the cell, along with caspase- 9 activation, which, in turn, activates caspase-3, ultimately resulting in degradation of activated caspase-3 substrate proteins $[8,9]$. These observations indicate that cross talk between the two pathways is mediated by $\mathrm{tBid}[10,11]$.

Findings from recent studies have indicated that marine organisms are a novel and rich source of bioactive compounds [12-14]. Among them, green seaweeds in the genus Enteromorpha have been used as an important healthcare food and a pharmaceutical product in Asian communities [15,16]. Of these, Enteromorpha linza is the most important economic seaweed cultured in temperate seaside areas of the northwest Pacific, including Korea, Japan, and China. Extracts of this seaweed have antimicrobial and antifungal activities [17]. Some recent studies have suggested that extracts of $E$. linza may exert immunological, antioxidant, and humectant activities [18,19]; however, the molecular mechanisms of their anti-proliferative actions on malignant cell growth have not yet been examined. In the present study, we investigated the anti-cancer activity of a methyl alcohol extract of $E$. linza (MEEL) in a U937 human leukemia cell model during the course of our screening program for bioactive marine natural products from seaweeds. Our data indicate that the MEEL induced apoptosis in U937 cells via a signaling cascade of extrinsic as well as intrinsic pathways.

\section{EXPERIMENTAL}

\section{Reagents}

4,6-Diamidino-2-phenyllindile (DAPI), propidium iodide (PI), and 3-(4,5-dimethyl-2-thiazolyl)-2,5diphenyl-2H-tetrazolium bromide (MTT) were purchased from Sigma-Aldrich (St. Louis, MO). RPMI 1640 medium and fetal bovine serum (FBS) were purchased from GIBCO-BRL (Gaithersburg, MD), and a caspase activity assay kit was obtained from R\&D Systems (Minneapolis, MN). A general and potent inhibitor of caspase (z-VAD-fmk) was obtained from Calbiochem (San Diego, CA). A DNA staining kit (CycleTEST'T PLUS Kit) and an enhanced chemiluminescence (ECL) kit were purchased from Becton Dickinson (San Jose, CA) and Amersham (Arlington Heights, IL), respectively. The MEEL was purchased from Jeju BioResource Extract Bank (Jeju, Republic of Korea). Any other chemicals not specifically cited above were purchased from Sigma-Aldrich.

\section{Cell culture}

U937 cells were obtained from the American Type Culture Collection (Rockville, MD) and cultured in RPMI 1640 medium supplemented with $10 \%$ heat-inactivated FBS, $1 \%$ penicillin/streptomycin (Gibco-BRL) at $37{ }^{\circ} \mathrm{C}$ and $5 \% \mathrm{CO}_{2}$. MEEL was dissolved in dimethyl sulfoxide (DMSO) as a stock solution at a 50 $\mathrm{mg} / \mathrm{ml}$ concentration, and the stock solution was then diluted with medium to the desired concentration prior to use.

\section{Cell viability assay}

U937 cells were seeded in 6-well plates at a density of $1 \times 10^{5}$ cells per well. The cells were treated with various concentrations of the MEEL for $48 \mathrm{~h}$. MTT working solution was then added to the culture plates and was incubated continuously at $37{ }^{\circ} \mathrm{C}$ for $3 \mathrm{~h}$. The culture supernatant was completely removed from the wells, and DMSO was added to completely dissolve the formazan crystals. The absorbance of each well was measured at $540 \mathrm{~nm}$ with a microplate reader (Molecular Devices, Palo Alto, CA). The effect of the MEEL on the inhibition of cell growth was assessed as the percentage of cell viability, where the vehicle-treated cells were considered $100 \%$ viable.

\section{DAPI staining}

After treatment with the MEEL, the cells were harvested, washed with cold phosphate-buffered saline (PBS), and fixed with $3.7 \%$ paraformaldehyde in PBS for $10 \mathrm{~min}$ at room temperature. The cells were stained with a DAPI solution for $10 \mathrm{~min}$ at room temperature, washed twice more with PBS, and analyzed using a fluorescence microscope (Carl Zeiss, Oberkochen, Germany).

\section{DNA fragmentation assay}

The cells were lysed in a buffer containing 10 $\mathrm{mM}$ Tris- $\mathrm{HCl} \mathrm{pH}$ 7.4, $150 \mathrm{mM} \mathrm{NaCl}, 5 \mathrm{mM}$ EDTA, and $0.5 \%$ Triton $\mathrm{X}-100$ for $30 \mathrm{~min}$ on ice. The lysates were vortexed and cleared by 
centrifugation at $14,000 \mathrm{rpm}$ for $20 \mathrm{~min}$. The DNA in the supernatant was extracted using a 25:24:1 $(\mathrm{v} / \mathrm{v} / \mathrm{v})$ equal volume of neutral phenol: chloroform: isoamyl alcohol and analyzed electrophoretically on $1.5 \%$ agarose gels containing $0.1 \mu \mathrm{g} / \mathrm{ml}$ ethidium bromide $(\mathrm{EtBr})$.

\section{Flow cytometry analysis}

After treatment with the MEEL, the cells were harvested, washed once with PBS, and fixed in ice-cold $70 \%$ ethanol. The cells were incubated at $4{ }^{\circ} \mathrm{C}$ for $1 \mathrm{~h}$, washed twice with PBS, and resuspended in a cold PI solution containing 100 $\mu \mathrm{g} / \mathrm{ml}$ RNase A, $50 \mu \mathrm{g} / \mathrm{ml} \mathrm{Pl}, 0.1 \%$ sodium citrate, and $1 \% \mathrm{NP}-40$, and further incubated on ice for $30 \mathrm{~min}$ in the dark. The stained cells were analyzed by flow cytometry (FACS Caliber; Becton Dickinson, San Jose, CA), and CellQuest software was used to determine the relative DNA content based on the presence of red fluorescence. The sub-G1 population was calculated to estimate the apoptotic cell population.

\section{Mitochondrial membrane potential (MMP) values}

The MMP $(\Psi \mathrm{m})$ of intact cells was measured by flow cytometry using the dual-emission potentialsensitive probe $\mathrm{JC}-1$. After treatment with the MEEL, the cells were collected and incubated with $10 \mu \mathrm{M} \mathrm{JC}-1$ for $20 \mathrm{~min}$ at $37^{\circ} \mathrm{C}$ in the dark. The cells were then washed once with PBS and analyzed by flow cytometry.

\section{Caspase activity}

Caspase activities were determined with colorimetric assay kits that use synthetic tetrapeptides (Asp-Glu-Val-Asp (DEAD) for caspase-3; Ile-Glu-Thr-Asp (IETD) for caspase-8; Leu-Glu-His-Asp (LEHD) for caspase-9 labeled with $p$-nitroaniline (pNA), according to the manufacturer's protocol. Briefly, equal amounts of cell lysates were collected and incubated with the supplied reaction buffer containing DTT and DEAD-pNA, IETD-pNA, or LEHD-pNA as the substrate at $37{ }^{\circ} \mathrm{C}$ for $2-3 \mathrm{~h}$. The reactions were assessed for changes in absorbance at 405 $\mathrm{nm}$ using a microplate reader.

\section{Western blot analysis}

Cells were harvested and washed once with icecold PBS and gently lysed for $20 \mathrm{~min}$ in ice-cold lysis buffer (40 mM Tris [pH 8.0], $120 \mathrm{mM}, \mathrm{NaCl}$, $0.5 \%$ NP-40, $0.1 \mathrm{mM}$ sodium orthovanadate, 2 $\mu \mathrm{g} / \mathrm{ml}$ leupeptin, and $100 \mu \mathrm{g} / \mathrm{ml}$ phenymethylsulfonyl fluoride). The supernatants were collected and protein concentrations were determined using a Bio-Rad protein assay kit (Bio-Rad, Hercules, CA). Equal amounts of protein extracts were denatured by boiling at 95 ${ }^{\circ} \mathrm{C}$ for $5 \mathrm{~min}$ in sample buffer $(0.5 \mathrm{M}$ Tris- $\mathrm{HCl}, \mathrm{pH}$ $6.8,4 \%$ SDS, $20 \%$ glycerol, $0.1 \%$ bromophenol blue, $10 \% \beta$-mercaptoethanol) at a ratio of 1:1. Samples were stored at $-80^{\circ} \mathrm{C}$ or immediately used for immunoblotting. Aliquots containing $30-$ $50 \mu \mathrm{g}$ total protein were separated on SDSpolyacrylamide gels and transferred to PVDF membranes (Schleicher \& Schuell, Keene, NH). Membranes were then incubated overnight at 4 ${ }^{\circ} \mathrm{C}$ with primary antibodies, probed with enzymelinked secondary antibodies, and detected using an enhanced chemiluminescence detection system. The primary antibodies were purchased from Santa Cruz Biotechnology Inc. (Santa Cruz, $\mathrm{CA}$ ) and Calbiochem (Cambridge, MA). The peroxidase-labeled donkey anti-rabbit immunoglobulin and peroxidase-labeled sheep anti-mouse immunoglobulin were purchased from Amersham.

\section{Statistical analysis}

Each result is expressed as mean \pm standard deviation of data obtained from triplicate experiments. The statistical analysis was performed using a paired Student's t-test. Differences at $p<0.05$ were considered significant.

\section{RESULTS}

Inhibition of cell viability and induction of apoptosis by the MEEL

As shown in Fig. $1 \mathrm{~A}$, as the concentration of MEEL increased, cell viability decreased in a dose-dependent manner. For example, when U937 cells were treated with 200 and $250 \mu \mathrm{g} / \mathrm{ml}$ MEEL, their cell viability decreased to 65.9 and $38.1 \%$, respectively, compared with that in untreated control cells. In addition to the decrease in cell viability, MEEL-treated U937 cells also exhibited a significant cell shrinkage and a reduction in cell density (Fig 1B).

To examine whether the inhibited growth caused by the MEEL was related to the induction of apoptosis, we analyzed three established criteria for assessing apoptosis. First, morphological changes in MEEL-treated or untreated U937 cells were determined using DAPI staining. As shown in Fig 1C, the control cells displayed intact nuclear structure, whereas cells treated with the MEEL displayed apoptotic morphological characteristics such as chromosomal condensation and nuclear fragmentation. 
Second, we observed nucleosomal DNA ladder formation by agarose gel electrophoresis in U937 cells treated with > $200 \mu \mathrm{g} / \mathrm{ml}$ MEEL for $48 \mathrm{~h}$, whereas DNA from untreated control cells showed barely detectable fragmentation (Fig. 1D). Third, the degree of apoptosis in cells treated with the MEEL was determined by flow cytometry to detect hypodiploid cell populations. As shown in Fig. 1E, treating the U937 cells with the MEEL resulted in increased accumulation of sub-G1 phase cells in a dose-dependent manner. These results suggest that suppressing U937 cell growth by MEEL treatment occurs via the induction of apoptosis.

\section{Effect of the MEEL on the levels of apoptosis- related proteins and the values of MMP}

We determined the expression of the apoptosisassociated proteins using Western blotting after U937 cells were treated with the MEEL for $48 \mathrm{~h}$ to investigate the mechanism of how the MEEL induces apoptosis in U937 cells. As shown in Fig
2A, the levels of death receptor 4 (DR4), DR5, and Fas ligand (FasL) were enhanced after U937 cells were treated with the MEEL. The expression of the anti-apoptotic proteins Bcl-2 and $\mathrm{Bcl}-\mathrm{xL}$ was suppressed; however, that of the pro-apoptotic proteins Bax and Bad increased in response to MEEL treatment (Fig 2B). Moreover, although we did not detect the truncated form of the pro-apoptotic protein Bid, treatment with the MEEL resulted in a decreased level of full-length Bid and the appearance of a tBid band, which reflected Bid cleavage and activation.

We also examined whether the MEEL induced apoptosis by modulating the expression of inhibitor of apoptosis protein (IAP) family members. The results indicated that MEEL treatment caused down-regulation of XIAP as well as the clAP1 and clAP2 proteins in a concentration-dependent manner (Fig 2C). We further tested the effect of MEEL on MMP, a characteristic feature of apoptosis.

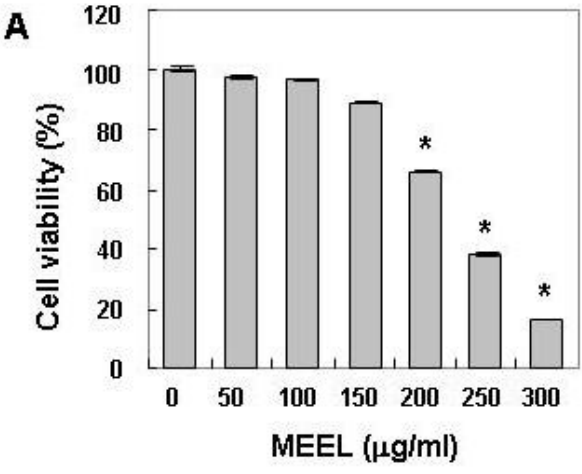

D

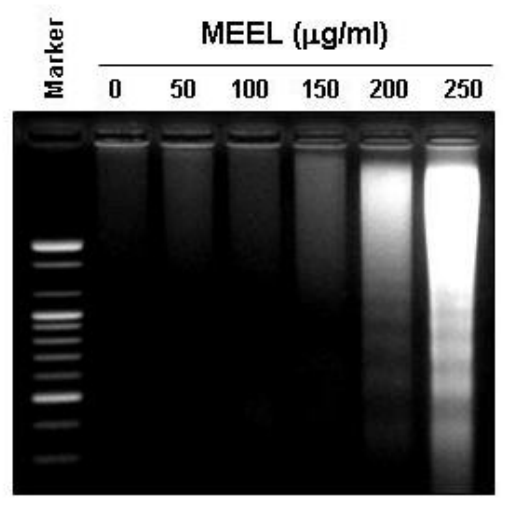

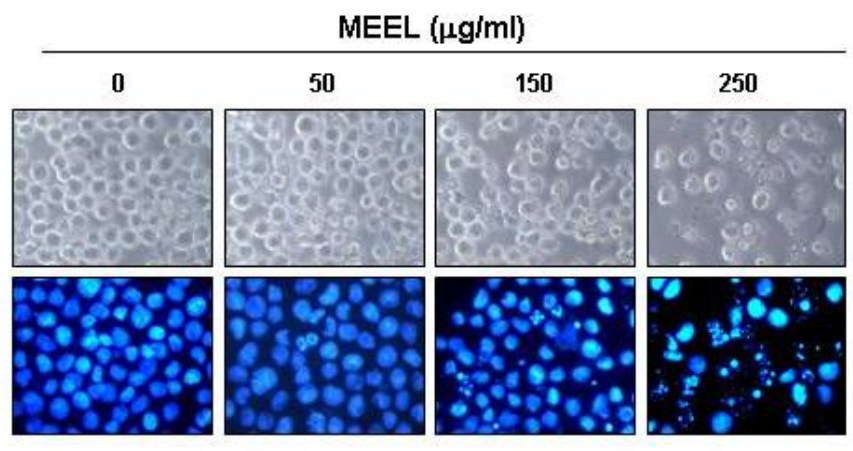

E

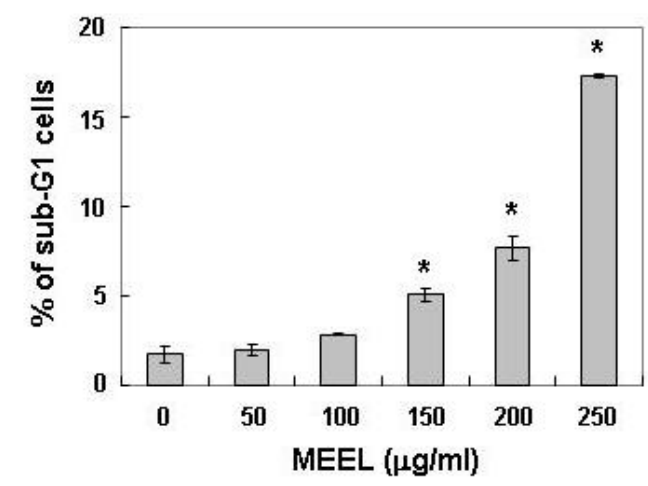

Figure 1: Inhibition of viability and induction of apoptosis by MEEL in U937 cells. (A) Cells were treated with the indicated concentrations of the MEEL for $48 \mathrm{~h}$. Cell viability was determined by the MTT assay. (B) Cell morphology was visualized by light microscopy. Magnification, $\times 200$. (C) The cells were fixed, and nuclei were stained with DAPI solution and photographed with a fluorescent microscope using a blue filter. Magnification, $\times$ 400. (D) To analyze DNA fragmentation, genomic DNA was extracted, electrophoresed on a $1.5 \%$ agarose gel, and visualized by EtBr staining. (E) To quantify the degree of apoptotic cells, sub-G1 DNA content was evaluated using flow cytometry. Results are expressed as a percentage of the vehicle treated control \pm standard deviation of three separate experiments. Significance was determined by Student's $t$-test ( ${ }^{*} p<0.05$ vs. untreated control) 
As shown in Fig. 2D, MMP treatment of U937 cells resulted in loss of the MMP compared with that in untreated controls as measured by $\mathrm{JC}-1$ staining, with green fluorescence depicting apoptotic cells. The results indicate that the MEEL induced mitochondrial membrane hyperpolarization by depolarization.

\section{Activation of caspases by MEEL treatment}

We next investigated whether MEEL treatment activated caspases. As shown in Fig. 3A and B, MEEL treatment induced a concentrationdependent increase in the levels of activecaspases and their in vitro activities. Caspase- 8 and -9 are initiator caspases of the death receptor-mediated and the mitochondriamediated apoptotic pathways, respectively. Subsequent results revealed that proteolytic activation of caspase-3 and progressive cleavage products of poly(ADP-ribose) polymerase (PARP) and phospholipase $\mathrm{C}_{\gamma}-1$ (PLC-y1) proteins, downstream targets of

A
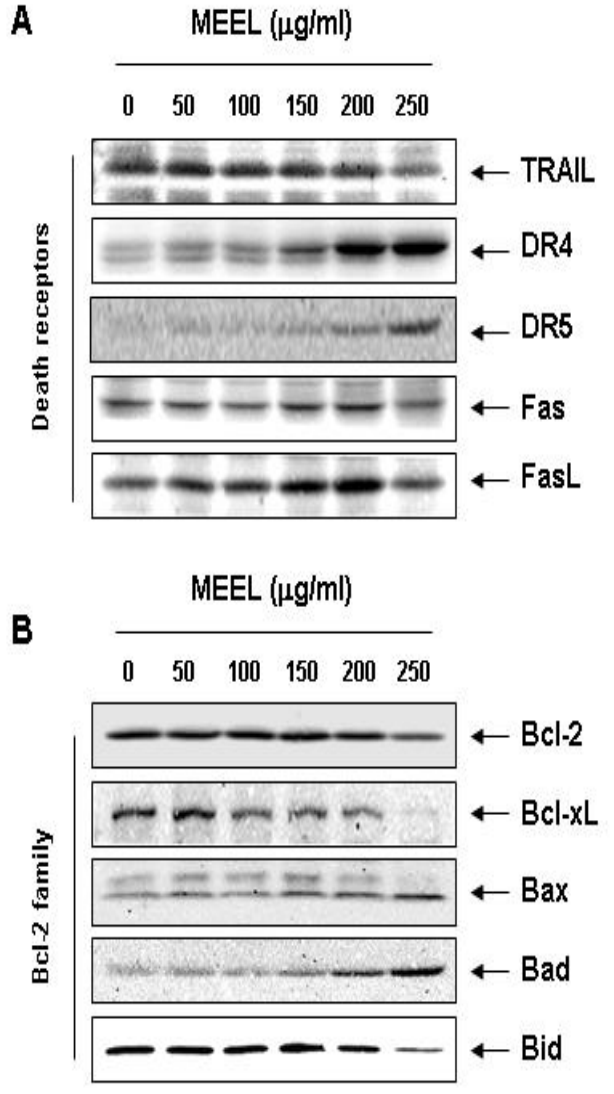

activated caspase-3 [20,21], occurred in U937 cells treated with the MEEL, which is a hallmark of cells undergoing apoptosis.

\section{Inhibition of caspase-dependent apoptosis by MEEL}

To confirm the role of caspase activation in MEEL-induced U937 cell apoptosis, we next blocked caspase activity using a general and potent inhibitor of caspase, z-VAD-fmk. U937 cells were pre-incubated with z-VAD-fmk followed by a $48 \mathrm{~h}$ co-incubation with the MEEL. The results of nuclear morphology, flow cytometry and agarose gel electrophoresis indicated that the z-VAD-fmk pretreatment significantly inhibited chromatin condensation, DNA fragmentation, and accumulation of the sub-G1 population following MEEL treatment (Fig. 4). These results indicate that the MEEL induced apoptotic death in U937 cells through a caspase-dependent pathway.

C
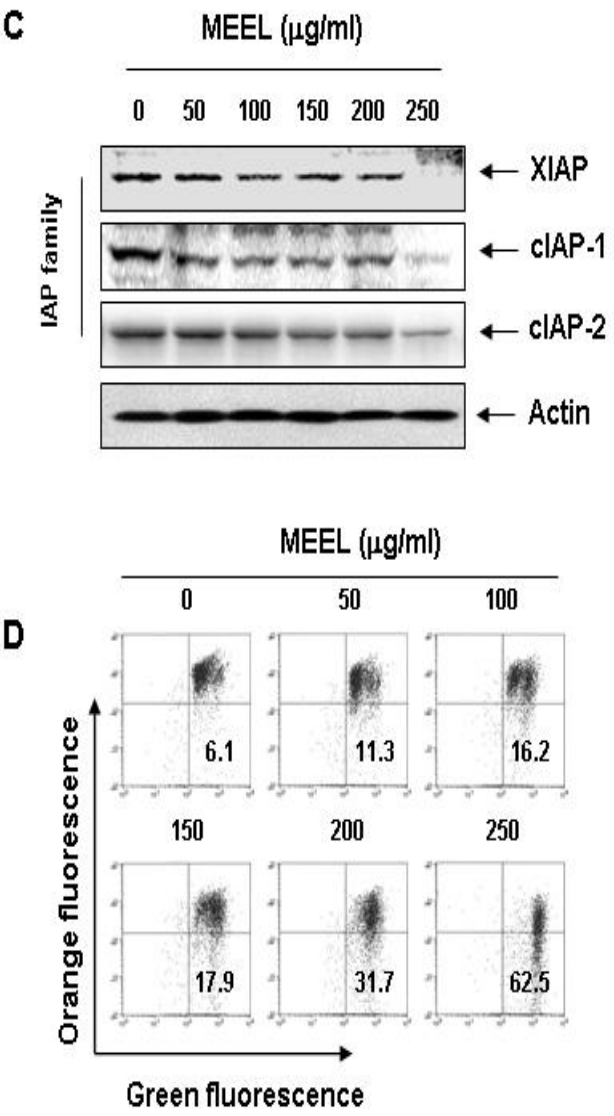

Figure 2: Effect of MEEL on the expression levels of apoptosis-related proteins and loss of the MMP by MEEL treatment in U937 cells. (A-C) Cells were treated with the indicated concentrations of the MEEL for $48 \mathrm{~h}$. The cells were lysed, and then equal amounts of cell lysates were separated on SDS-polyacrylamide gels and transferred to membranes. The membranes were probed with the indicated antibodies, and the proteins were visualized using an ECL detection system. Actin was used as the internal control. (D) The cells were collected and incubated with JC-1 for 30 min. The cells were washed once with PBS and analyzed by flow cytometry. Results are expressed as the mean of two independent experiments 
A

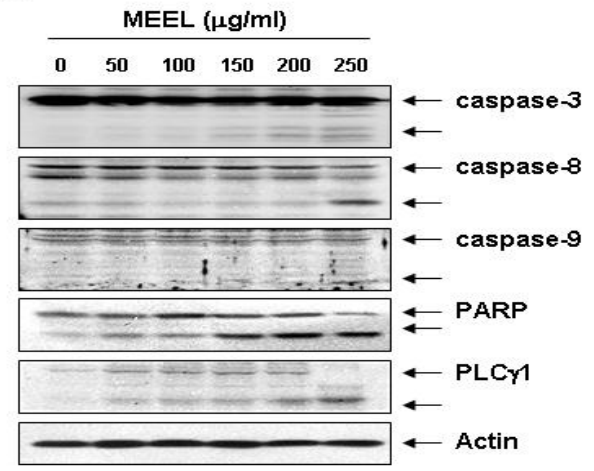

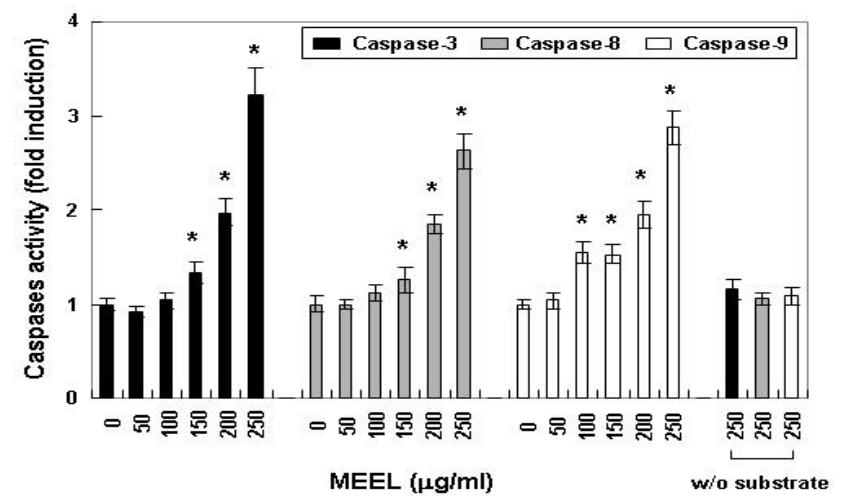

Figure 3: Activation of caspases and the degradation of PARP and PLC- $\mathrm{y} 1$ by treatment with MEEL in U937 cells. (A) After treatment with MEEL for $48 \mathrm{~h}$, equal amounts of cell lysates were separated on SDSpolyacrylamide gels and transferred to membranes. The proteins were visualized using an ECL detection system. Actin was used as the internal control. (B) The aliquots obtained from cells were assayed for in vitro caspase-3, 8, and -9 activity using DEVD-pNA, IETD-pNA, and LEHD-pNA as substrates, respectively, at $37^{\circ} \mathrm{C}$ for $1 \mathrm{~h}$. The released fluorescent products were measured. Significance was determined by Student's $t$-test $\left({ }^{*} p<0.05\right.$ vs. untreated control)

A

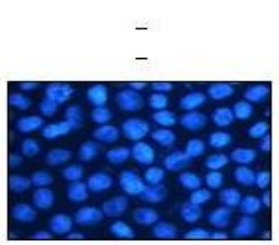

B

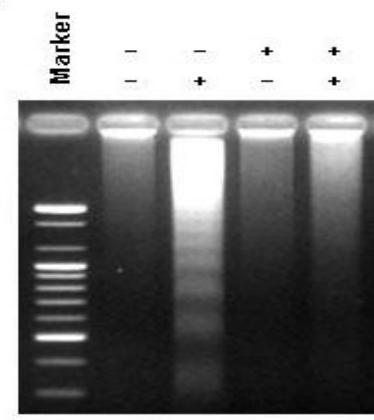

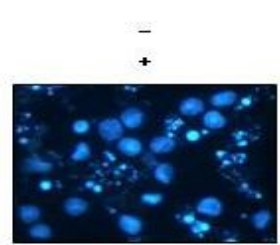
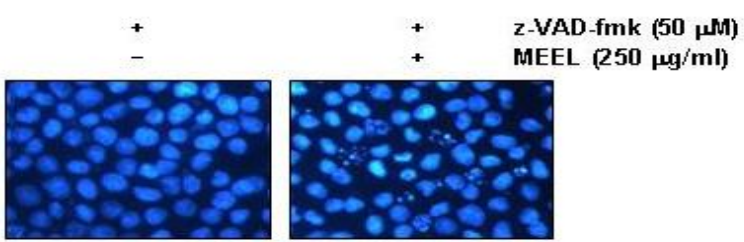

C

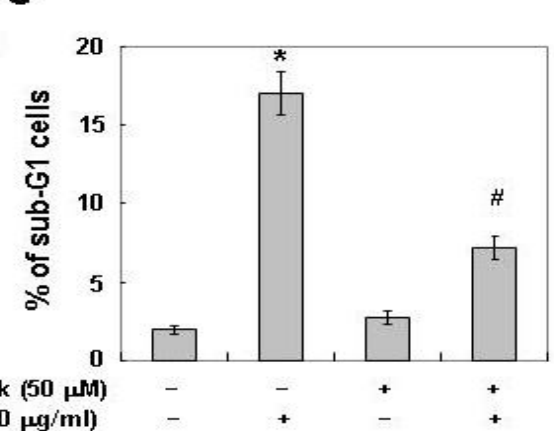

Figure 4: Inhibition of MEEL-induced apoptosis by z-VAD-fmk in U937 cells. Cells were pretreated for $1 \mathrm{~h}$ with or without z-VAD-fmk, and then with the MEEL for an additional $48 \mathrm{~h}$. (A) The cells were stained with DAPI and photographed with a fluorescence microscope. Magnification, $\times 400$. (B) DNA fragmentation was analyzed by extracting the fragmented DNA and separating it on $1.5 \%$ agarose gel electrophoresis with $\mathrm{EtBr}$. (C) The sub-G1 DNA content was evaluated by flow cytometry. Significance was determined by Student's $t$-test $\left({ }^{*} p<0.05\right.$ vs. untreated control; ${ }^{\#} p<0.05$ vs. MEEL-treated cells)

\section{DISCUSSION}

Although the extracts and components isolated from $E$. linza possess a wide range of biological activities that may contribute to health beneficial effects, the mechanisms of the anti-proliferative actions on malignant cell growth have not yet been elucidated. In the present study, we investigated the effects of a MEEL on U937 cells in vitro. Our results show that the MEEL exhibited a potent pro-apoptotic effect on U937 cells and that such apoptosis occurred in a caspase activation-dependent manner.

Failure of apoptosis leads to an imbalance in cell number, which, in turn, leads to tumorigenesis; therefore, induction of apoptosis in malignant cells has emerged as an important strategy for cancer therapy. Among two major apoptotic pathways, the extrinsic apoptotic pathway requires recruitment of the death receptorassociated death domain and caspase-8, which 
results in caspase-8 activation and subsequent activation of its downstream executioner caspases including caspase- 3 and -7 and apoptosis $[4,9,10]$. In addition, activated caspase-8 converts Bid to tBid, leading to mitochondrial depolarization [4,6,7]. Although tBid plays an important role leading to the formation of mitochondrial conformational changes, mitochondrial dysfunction through changes in membrane permeability and subsequent loss of MMP have been implicated as key apoptotic mechanisms in the mitochondrial apoptotic pathway $[3,5,22]$. In the mitochondria-mediated pathway, cytochrome $\mathrm{c}$ is released from the intramembrane space into the cytosol along with mitochondrial dysfunction and promotes caspase-9 activation, which, in turn, activates executioner caspases, ultimately resulting in cleavage of its target substrate proteins such as PARP and PLC-y1 [20,21]. Our results show that the MEEL induced death receptor-associated proteins such as DR4, DR5, and FasL, activated caspase-8, and reduced whole Bid proteins, which may be related to tBid activation. Our data also clearly indicate that treatment with the MEEL led to the collapse of the MMP and activation of caspase-9. These data indicate that extrinsic and intrinsic pathways may have contributed, at least in part, to MEELinduced apoptosis in U937 cells.

Furthermore, Bcl-2 family proteins regulate mitochondria-dependent apoptosis with the balance of anti- and pro-apoptotic members arbitrating life-and-death decisions [23,24]. As shown in Fig. 2, MEEL treatment resulted in a significant increase in Bax and Bad expression and a decrease in $\mathrm{Bcl}-2$ and $\mathrm{Bcl}-\mathrm{xL}$ expression, suggesting that changes in the ratio of proapoptotic and anti-apoptotic Bcl-2 family proteins might contribute to the apoptosis-promotion activity of the MEEL. Additionally, many previous clinical data have indicated that over-expression of IAP family proteins correlates with apoptosis resistance in transformed cell types and in a variety of human tumors $[25,26]$. These proteins, which are largely over-expressed by most tumors, promote tumor cell survival due to direct inhibition by binding to several caspases and protect cells from apoptosis induced by a variety of agents.

Based on our findings, we propose a MEELinduced apoptosis signaling pathway as shown in Fig 5. First, the death receptor-mediated pathway is initiated by ligation of the transmembrane death receptor to activate membrane-proximal caspases (caspase-8), which, in turn, activate effector caspases such as caspases-3. Second, the mitochondrial-mediated pathway requires disruption of the mitochondrial membrane, which induces activation of caspase- 9 and thereby initiates the apoptotic caspase cascade. In addition, cross talk between the two pathways is mediated by tBid, which may act as a potential feedback loop to amplify MEEL-induced caspase-dependent apoptosis.

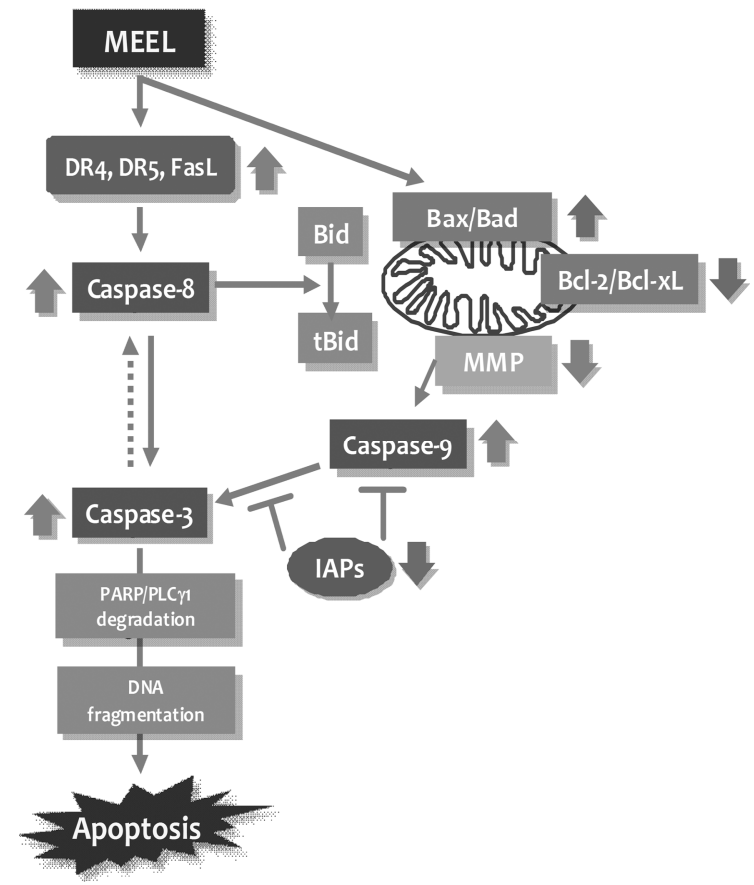

Figure 5: Schematic diagram depicting MEEL-induced apoptosis in U937 cells

\section{CONCLUSION}

The present study demonstrates a potent anticancer activity of the MEEL in vitro and elucidates the molecular mechanisms in U937 leukemia cells. These novel phenomena have not been described previously and provide important new insights into the anti-cancer effects of the MEEL. Therefore, it is possible that MEEL may provide a potential strategy for increasing the efficacy of chemotherapeutics in U937 cells.

\section{ACKNOWLEDGEMENT}

This research was supported by Blue-Bio Industry RIC (RIC08-06-07) at Dongeui University under the RIC program of the Ministry of Knowledge Economy and Busan city, Republic of Korea. 


\section{REFERENCES}

1. Kerr JF, Wyllie AH, Currie AR. Apoptosis: a basic biological phenomenon with wide-ranging implications in tissue kinetics. Br J Cancer 1972; 26. 239-257.

2. Lawen A. Apoptosis-an introduction. Bioessays 2003; 25 888-896.

3. Korsmeyer SJ, Wei MC, Saito M, Weiler S, Oh KJ, Schlesinger $\mathrm{PH}$. Pro-apoptotic cascade activates $B I D$, which oligomerizes BAK or BAX into pores that result in the release of cytochrome $c$. Cell Death Differ 2000; 7: 1166-1173.

4. Jin Z, El-Deiry WS. Overview of cell death signaling pathways. Cancer Biol Ther 2005; 4: 139-163.

5. Luo X, Budihardjo I, Zou H, Slaughter C, Wang X. Bid, a $B c / 2$ interacting protein, mediates cytochrome $c$ release from mitochondria in response to activation of cell surface death receptors. Cell 1998; 94: 481-490.

6. Budihardjo I, Oliver $H$, Lutter $M$, Luo $X$, Wang $X$. Biochemical pathways of caspase activation during apoptosis. Annu Rev Cell Dev Biol 1999; 15: 269290.

7. Elmore S. Apoptosis: a review of programmed cell death. Toxicol Pathol 2007; 35: 495-516.

8. Lazebnik YA, Kaufmann SH, Desnoyers S, Poirier GG, Earnshaw WC. Cleavage of poly(ADP-ribose) polymerase by a proteinase with properties like ICE. Nature 1997; 371: 346-347.

9. Kroemer G, Reed JC. Mitochondrial control of cell death. Nat Med 2000; 6: 513-519.

10. Ashkenazi A, Dixit VM. Death receptors: signaling and modulation. Science 1998; 281: 1305-1308.

11. Lee EW, Seo J, Jeong $M$, Lee S, Song J. The roles of $F A D D$ in extrinsic apoptosis and necroptosis. BMB Rep 2012; 45: 496-508.

12. Raven JA, Taylor R. Macroalgal growth in nutrientenriched estuaries: a biogeochemical and evolutionary perspective. Water Air Soil Poll 2003; 3. 7-26.

13. Lordan S, Ross RP, Stanton C. Marine bioactives as functional food ingredients: potential to reduce the incidence of chronic diseases. Mar Drugs 2011; 9 . 1056-1100.
14. Glaser $K B$, Mayer $A M$. A renaissance in marine pharmacology: from preclinical curiosity to clinical reality. Biochem Pharmacol 2009; 78: 440-448.

15. Lahaye $M$, Robic A. Structure and functional properties of ulvan, a polysaccharide from green seaweeds. Biomacromolecules 2007; 8: 1765-1774.

16. Kim SK, Pangestuti R, Rahmadi P. Sea lettuces: culinary uses and nutritional value. Adv Food Nutr Res 2011; 64: $57-70$.

17. Cho HB, Lee $H H$, Lee OH, Choi HS, Choi JS, Lee BY. Clinical and microbial evaluation of the effects on gingivitis of a mouth rinse containing an Enteromorpha linza extract. J Med Food. 2011; 14: 1670-1676.

18. Zhang Z, Wang $X, Y u S$, Yin L, Zhao M, Han $Z$. Synthesized oversulfated and acetylated derivatives of polysaccharide extracted from Enteromorpha linza and their potential antioxidant activity. Int $\mathrm{J}$ Biol Macromol 2011; 49: 1012-1015.

19. Zhang Z, Wang $X$, Zhao $M$, Yu S, Qi $H$. The immunological and antioxidant activities of polysaccharides extracted from Enteromorpha linza. Int J Biol Macromol 2013; 57C: 45-49.

20. Tewari M, Quan LT, O'Rourke K, Desnoyers S, Zeng Z, Beidler DR, Poirier GG, Salvesen GS, Dixit VM. Yama/CPP32 beta, a mammalian homolog of CED-3, is a CrmA-inhibitable protease that cleaves the death substrate poly(ADP-ribose) polymerase. Cell 1995; 81: 801-809.

21. Bae SS, Perry DK, Oh YS, Choi JH, Galadari SH, Ghayur T, Ryu SH, Hannun YA, Suh PG. Proteolytic cleavage of phospholipase C-gamma1 during apoptosis in Molt-4 cells. FASEB J 2000; 14: 10831092.

22. Esposti MD. The roles of Bid. Apoptosis 2002; 7: 433440.

23. Tsujimoto $Y$, Shimizu S. Bcl-2 family: life-or-death switch. FEBS Lett 2000; 466: 6-10.

24. Kang $\mathrm{MH}$, Reynolds $\mathrm{CP}$. Bcl-2 inhibitors: targeting mitochondrial apoptotic pathways in cancer therapy. Clin Cancer Res 2009; 15: 1126-1132.

25. LaCasse EC, Mahoney DJ, Cheung HH, Plenchette S, Baird S, Korneluk RG. IAP-targeted therapies for cancer. Oncogene 2008; 27: 6252-6275.

26. Hunter AM, LaCasse EC, Korneluk RG. The inhibitors of apoptosis (IAPs) as cancer targets. Apoptosis 2007; 12: 1543-1568. 